\title{
POTRET LHKPN dan LPPDK \\ DALAM PEMILIHAN GUBERNUR DAN WAKIL GUBERNUR DI PROVINSI JAWA BARAT DAN JAWA TIMUR TAHUN 2018 UNTUK MEWUJUDKAN PEMILU BERINTEGRITAS
}

\author{
Nurlia Dian Paramita \\ Peneliti Senior Jaringan Pendidikan Pemilih Untuk Rakyat (JPPR) \\ Jalan Manggarai Utara 1 no H-4, Tebet, \\ Jakarta Selatan \\ E-mail: ndipa21@gmail.com
}

\begin{abstract}
Report of State Official Assets (LHKPN) becomes one of the evidences for the amount of financial ownership owned by candidates for head and deputy regional head. This report is submitted as an effort to ensure data transparency and to prevent potential out-of-bounds money circulation during the campaign period. Law 10 of 2016 requires all participants in the head and deputy regional head elections to report the final financing results of activities in the campaign fund stage, namely Report of Receipt and Expenditure of Campaign Funds (LPPDK). Both report formats lead to the creation of elections with integrity. LHKPN does not have a standard assessment of the accuracy of assets owned by regional head candidates. The LPPDK as the final accountability report can only be reviewed from the results of the audit report announced by the KPU. Using a qualitative method, this paper is intended to explain the validity of the model as an instrumentation to create a fair election as well as to convey ideas about a more credible campaign funding reporting for the next local election
\end{abstract}

Keywords: Integrity Elections, LHKPN, LPPDK, and the Election of Governor and Vice Governor in 2018

\section{Abstraksi}

Laporan Harta dan Kekayaan Pejabat Negara (LHKPN) menjadi salah satu bukti atas jumlah kepemilikan keuangan yang dimiliki oleh kontestan calon kepala dan wakil kepala daerah. Laporan ini diberikan sebagai upaya transparansi data dan pencegahan tindak pidana korupsi dengan mengacu pada kejujuran calon kepala 
daerah. UU 6 tahun 2020 mensyaratkan semua peserta pemilihan kepala dan wakil kepala daerah untuk melaporkan hasil pembiayaan akhir atas aktivitas dalam tahapan dana kampanye yakni pada LPPDK. Kedua format laporan tersebut bermuara pada terciptanya pemilu yang berintegritas. LHKPN tidak memiliki standar penilaian tentang keakuratan harta kekayaan yang dimiliki calon kepala daerah. LPPDK sebagai laporan akhir akuntabilitasnya hanya bisa ditinjau dari hasil laporan audit yang diumumkan oleh KPU. Dengan metode kualitatif, tulisan ini hendak memaparkan kebenaran model pelaporan tersebut sebagai instrument mewujudkan pemilu berintegritas sekaligus menyampaikan gagasan tentang pelaporan pendanaan kampanye Pilkada berikutnya yang lebih kredibel.

Kata Kunci: pemilu berintegritas; LHKPN; LPPDK; dan Pemilihan Gubernur dan Wakil Gubernur Tahun 2018

\section{Pendahuluan}

Dalam desain kelembagaan pemilu diperlukan sebuah upaya taktis untuk mengatur sirkulasi akuntabilitas atas hasil pemilu. Proses ini memerlukan kerjasama antar pihak guna memastikan peran yang dilakukan dalam mewujudkan integritas pemilu. Dana Kampanye berdasarkan UU 6 tahun 2020 pasal 74 dan 75 adalah Pelaporan aktivitas pendanaan kampanye yang dilakukan Pasangan Calon Kepala Daerah sebagai upaya pengaturan pendanaan kampanye yang dilakukan secara transparan dan akuntabel sesuai standar akuntansi keuangan. Sementara definisi Pada PKPU 13/2020 dijelaskan Dana Kampanye adalah sejumlah biaya berupa uang, barang dan jasa yang digunakan Pasangan Calon dan/atau Partai Politik atau Gabungan Partai Politik yang mengusulkan Pasangan Calon untuk membiayai kegiatan kampanye pemilihan. Terdapat periodesasi dalam pelaporan ini yakni penyerahan LADK, penyerahan LPSDK dan terakhir adalah LPPDK.
Kajian yang dilakukan dalam studi ini fokus kepada LPPDK. Dalam laporan penerimaan dan pengeluaran dana kampanye (LPPDK) tersaji laporan aktivitas pembiayaan kampanye yang dilakukan oleh pasangan calon kepala daerah. Sebelum pelaksanaan LPPDK terdapat sebuah upaya untuk menghadirkan aspek kejujuran pasangan calon, yakni regulasi PKPU 13 tahun 2020, yang memberikan Informasi Laporan Harta dan Kekayaan Pejabat Negara (LHKPN). Hal ini didorong sebagai mekanisme untuk menjaga kemandirian partai politik, calon anggota legislatif dan calon pejabat eksekutif dari pengaruh para penyumbang pendanaan pada saat mereka menduduki jabatan publik nanti. Kedua instrumen pelaporan tersebut dirancang untuk mampu mengidentifikasi hal-hal yang dilarang dalam UU 6/2020 serta penggunaan dana yang diluar kewenangan. Sementara informasi kekayaan yang sesuai dengan profil pendapatan juga diperlukan guna mencegah terjadinya korupsi sesuai dengan UU 28/1999 yang kemudian terinternalisasi dalam UU 
$6 / 2020$ sebagai syarat pendaftaran pencalonan pasangan kepala daerah (Fariz \& Ilyas, 2019) memberikan jabaran bahwa korupsi dan pemilu menjadi dua hal yang berkelindan satu dengan yang lainnya apalagi pilkada merupakan momentum transisi elit. Hal ini mengindikasikan bahwa praktek pendanaan kampanye berpotensi menciptakan hubungan koruptif antara penyumbang, parpol, kandidat yang didukungnya serta perilaku koruptif yang terjadi antara peserta pemilu dan voters. (Supriyanto \& Wulandari, 2013) mengungkapkan bahwa prinsip transparansi mengharuskan partai politik dan calon bersikap terbuka pada semua proses pengelolaan dana kampanye. Tujuan membuka daftar penyumbang dan laporan dana kampanye adalah menguji prinsip akuntabilitas yaitu memastikan tanggung jawab partai politik dan calon, bahwa dalam membelanjakan dana kampanye itu berlangsung rasional, sesuai etika, dan tidak bertentangan dengan hukum. Forum Asian Electoral Stakeholder Forum (AESF III) yang berlangsung di Bali, Indonesia seperti disampaikan (Wardani, 2016), menekankan bahwa pentingnya membangun demokrasi yang berpihak kepada hak-hak sipil, sumber daya dan etika hukum agar demokrasi terus berkembang dengan semangat keluhuran. Forum tersebut juga menghasilkan kesepakatan bahwa transparansi dan integritas merupakan pondasi kunci untuk pemilu yang jujur dan adil, hal ini harus disertai dengan data dan penggunaan informasi teknologi yang mampu membangun kepercayaan publik serta memberikan keuntungan terhadap pemilu yang transparan dan berintegritas. Hasil penelitian JPPR mengatakan bahwa LPPDK calon kepala daerah tidak transparan. Ditemukan kasus di mana besaran pengeluaran dari hasil pemantauan ternyata jauh lebih besar dibandingkan dengan nilai dalam laporan yang diserahkan pasangan calon. "Pelaporan dana kampanye hanya dianggap untuk memenuhi syarat. Dan KPU juga tidak melakukan audit lebih jauh terkait laporan dana kampanye tersebut" (Hafidz, 2015). Sementara (Larasati \& Latifah, 2018) juga mengungkapkan sulit untuk mengukur aspek LHKPN karena kekayaan yang tidak dilaporkan sesuai dengan prosedur di setiap tahunnya. Sementara (Dalilah, Selawati, dkk, 2019) menyampaikan bahwa dalam kajiannya terhadap potensi benturan kepentingan pada pendanaan pilkada, yang dilakukan dengan metode telesurvey LHKPN pasangan calon Pilkada tahun 2015, 2017 dan 2018 memiliki harta minus. Terdapat calon kepala/wakil kepala daerah yang mengeluarkan pendanaan untuk pilkada melebihi dari harta kas dan total harta kekayaan. Hal ini sejalan dengan kajian ICW (2018) yang mengatakan bahwa data yang diberikan oleh calon kepala daerah diduga banyak yang tidak sesuai dengan kondisi riil. Hal yang paling sering ditemukan adalah melaporkan jumlah kekayaan lebih sedikit dibanding yang sebenarnya. Malah ditemukan kandidat yang melaporkan harta kekayaannya minus. Namun tidak ada lembaga 
yang berkewenangan memberikan sanksi. KPK hanya sebatas mengumumkan dan menverifikasi data. Kajian ini bermaksud untuk menemukan apakah LHKPN dan LPPDK dapat menjadi indikator dalam menentukan sebuah pemilu berintegritas atau tidak. Dalam UU 6 Tahun 2020 terdapat aturan yang mengatakan pasangan calon wajib melaksanakan laporan dana kampanye secara transparan dan akuntabel sesuai standar akuntasi keuangan. Dalam hal ini LHKPN diperlukan sebagai "pintu masuk" guna menganalisis jumlah harta kekayaan pasangan calon. Hal ini sebagai petunjuk dalam menganalisa LPPDK apakah laporan yang dihasilkan sesuai dengan kemampuan pendanaan pasangan calon. Kajian ini hendak memberikan uraian apakah benar penyerahan LHKPN yang kemudian dilanjutkan dengan penyerahan LPPDK mampu mendukung terwujudnya pemilu berintegritas.

\section{Metode Penelitian}

Dalam penelitian ini, penulis menggunakan metode kualitatif dengan studi kepustakaan LPPDK Pilgub Pasangan Calon Kepala Daerah 2 paslon Provinsi Jatim dan 4 paslon Provinsi Jabar tahun 2018 yakni dokumen resmi yang dikeluarkan oleh lembaga penyelenggara pemilu, dalam hal ini KPU Provinsi Jabar dan KPU Provinsi Jatim. Studi ini memilih dua Provinsi tersebut dikarenakan jumlah kontestan dengan variasi jumlah LHKPN yang beragam termasuk terdapat calon yang tidak menyerahkan tanda terima dari KPK saat pencalonan pilkada. Di sisi lain Jawa Barat berdasarkan dari Jabar Dalam Angka 2020 mempunyai 18 kabupaten dan 9 kota wilayah dengan penduduk mencapai 49.316 juta jiwa dan Jawa Timur sebagaimana dalam Jatim Dalam Angka 2020 mempunyai 29 kabupaten dan 9 kota dengan jumlah penduduk mencapai 39.699 juta jiwa. Jumlah penduduk dan data LHKPN serta LPPDK paslon diperlukan untuk melihat dampak elektoral yang akan menghasilkan pemerintah daerah yang membangun kesejahteraan masyarakat. Pasangan calon di Jawa Barat berjumlah 4 pasangan dan Jawa Timur berjumlah 2 pasangan calon. Data LHKPN diperoleh dari sumber pemberitaan dari media selama rentang masa pilkada berlangsung. Hal ini dikarenakan pada situs kanal KPK melalui www.kpk.go.id ataupun acch.kpk.go.id penulis tidak mendapatkan informasi pemaparan LHKPN dari sumber tersebut. Selain itu penulis menggunakan data kajian para masyarakat sipil, akademisi dan guna mendapatkan keoptimalan data, tulisan ini juga menggunakan pemberitaan media massa cetak dan online.

\section{Perspektif Teori}

Dalam pasal $22 \mathrm{E}$ ayat 1 UUD 1945 disebutkan "Pemilihan umum dilaksanakan secara langsung, umum, bebas, rahasia, jujur dan adil, setiap lima tahun sekali" Hal ini menegaskan bahwa sebagai sebuah negara bangsa, Indonesia teguh mewujudkan demokrasi elektoral yang berintegritas. Reynolds \& Reilly (2016) menegaskan bahwa 
sistem politik yang akuntabel adalah sistem politik dimana pemerintah bertanggung jawab terhadap pemilih dengan pertanggungjawaban sebesar mungkin. Sementara dalam kajian Norris (2012) dijelaskan bahwa sebuah pemilihan yang diikuti oleh multipartai juga berpotensi menghasilkan politik patronase dimana terdapat keuntungan pribadi yang makin membuncah kemudian berpotensi merusak sektor publik. Yakni melemahkan legitimasi otoritas dan juga norma integritas. Dalam tinjauannya untuk mewujudkan rezim good governance sebagai konsekuensi pelaksanaan pemilihan elektoral, organisasi pada birokrasi pemerintah juga harus mampu menempatkan indikator ketidakberpihakan, efektifitas, efisiensi, tranparansi dan integritas. Khusus poin terakhir menjadi mekanisme akuntabilitas utama yang mampu menekankan pemilu untuk menghasilkan pemimpin daerah yang berintegritas, mewujudkan kesejahteraan sosial dan meningkatkan ekonomi masyarakat. Pemilu dalam hal ini, Pilkada yang kompetitif, meski sudah mengacu pada standar integritas elektoral, harus menguatkan syarat yang bermakna kebebasan informasi yakni media yang tidak memihak, adanya kelompok otonomi (partai politik, kelompok kepentingan dan gerakan sosial). Dalam kondisi ini pula juga dikatakan bahwa pemilu berintegritas akan mampu meminimalisir tindak perilaku korupsi dan negara memiliki tradisi pemberian jabatan bagi ASN/ birokrat dengan jalur prestasi di sektor publik. Norris lebih lanjut mengatakan bahwa dalam sebuah pemilihan elit penguasa juga telah mempelajari manipulasi pemilihan dengan mengurangi integritas pemilu sekaligus membatasi gerakan oposisi dan menekan perbedaan pendapat yang disebut sebagai electoral autocracies yang mengarah kepada otoritarianisme kompetitif. Hal ini mengingkari proses integritas yang menurut Muhammad (2019) dijalankan dengan prinsip regulasi yang jelas dan tegas, peserta pemilu yang taat aturan, pemilih yang cerdas dan partisipatif, birokrasi netral dan penyelenggara yang kompeten. Sementara dalam Global Commission on Election seperti dikutip Pasaribu \& Suradinata (2018) disebutkan bahwa integritas pemilu terlihat jika pemilu dapat terlaksana berdasarkan atas prinsip pemilu yang demokratis dan pemenuhan hak pilih universal dan kesetaraan politik pada standar internasional. Termasuk penyelenggara pemilu yang professional, tidak memihak dan transparan. Sehingga mewujudkan pengadilan konstitusi yang kuat, badan anti korupsi yang tegas, free and fair election dan adanya lembaga HAM yang mampu melindungi warganya juga mendukung adanya aspek integritas dalam sebuah proses pemilihan. Lebih lanjut dalam tinjauan Grynasviki (2010, hlm. 1) keberhasilan demokrasi bergantung pada bagaimana representasi calon kepala daerah terpilih mencerminkan kehendak masyarakatnya. "The success of representative democracy as a political system arguably hinges on the ability of the electorate to 
replace elected officials who fail to act in the public interest with others who will. This sort of democratic accountability requires (1) that ordinary citizens be able to pin credit or blame on the correct set of incumbent officials for their policy choices and (2) that citizens must reasonably believe that challengers will perform better in office." Sementara masyarakat pemilih mempunyai tantangan untukmemilih karena kandidat petahana memiliki insentif yang disediakan untuk memenangkan pemilihan kepala daerah sehingga ini berpeluang untuk menggagalkan terpilihnya kandidat baru yang mempunyai niat berbuat kebajikan termasuk melakukan perubahan ke arah yang lebih baik jika terpilih. Gaffar (2012) memberikan penekanan bahwa rakyat harus memilih para calon berdasarkan kapasitas dan integritas calon bukan berdasarkan make up atau money politic. Guna mewujudkan pemilu berintegritas maka penting untuk melihat tahapan teori sebagaimana yang disampaikan oleh Norris (2012). Mengidentifikasi apakah LHPKN dan LPPDK dalam kajian ini mampu memenuhi kualifikasi dalam mewujudkan iklim pemilu sebagaimana dijelaskan pada paragraf sebelumnnya.

Dalam UU 6 tahun 2020 pasal 7 huruf j dan 45 ayat 2 huruf c berbunyi "calon kepala daerah wajib menyerahkandaftarkekayaan pribadi berikut surat tanda terima laporan kekayaan calon yang sudah diperiksa oleh instansi yang berwenang" yakni mengenai laporan kekayaan daftar pribadi kontestan yang tertuang dalam LHKPN. Tinjauan Ahmad Suryono (2015) mengatakan bahwa LHKPN adalah sebuah upaya untuk para pejabat negara agar melakukan pelaporan terhadap harta kekayaan dengan penyampaian bersikap jujur, meskipun pada praktiknya dirasakan tidak efektif karena kejahatan atau menyamarkan hasil kejahatan semakin banyak dipilih oleh para pelaku. KPK pada praktiknya mampu melakukan penelusuran namun tidak bisa melakukan penindakan apabila menemukan hal yang janggal dalam proses pemeriksaan.

Sementara

berdasarkan

PKPU 13 tahun 2020 disebutkan bahwa Laporan Penerimaan dan Pengeluaran Dana Kampanye (LPPDK) adalah pembukuan yang memuat seluruh penerimaan dan pengeluaran Dana Kampanye. Menyajikan dalam bentuk uang, barang dan jasa. Untuk selanjutnya LPPDK diaudit oleh Kantor Akuntan Publik (KAP) yang diproses dalam waktu 15 (lima belas) hari terhitung sejak diterima dari KPU provinsi/ KIP dan KPU kab/kota. Hasil dari proses audit akan diserahkan KPU kepada pasangan calon dengan menginformasikan apakah laporan tersebut layak atau tidak.

Kajian dalam mewujudkan pemilu berintegritas ini dalam kerangka Norris (2012), Pertama, organisasi pemerintah dalam hal ini penyelenggara pemilu sebagai pengemban amanat tugas harus melaksanakan tugas secara independen, efektif, efisien dan transparan. Lembaga - lembaga pemerintah beserta penyelenggara pemilu, khususnya KPU dan Bawaslu 
mampumengidentifikasitransparansi bentuk LHKPN dan LPPDK. LHKPN dimaksudkan untuk menjelaskan posisi keuangan pasangan calon sebelum mencalonkan diri dan LPPDK menjadi bukti pencatatan transaksi yang dilakukan oleh pasangan calon selama pelaksanaan kampanye berlangsung. Kedua, adanya kelompok otonomi yakni gerakan sosial atau kelompok kepentingan yang berperan untuk berkontribusi dalam memberikan kritik atau masukan. Dalam hal ini pada proses pelaporan LHKPN dan LPPDK. Ketiga, menghasilkan pemimpin daerah yang menjunjung tinggi akuntabilitas sebagai dasar untuk mewujudkan kesejahteraan sosial dan naiknya perekonomian masyarakat. Dalam poin ketiga pada kajian ini digunakan sebagai tujuan akhir dari proses penelitian yang berorientasi kepada terwujudnya keberhasilan pembangunan daerah yang terhindar dari potensi electoral autocracies.

\section{Hasil dan Pembahasan}

\subsection{Potret Penyelenggaraan Pelaporan LHKPN}

Dalam upaya mewujudkan pencegahan terhadap tindak pidana korupsi, KPK, melalui UU 30 tahun 2002 pasal 6 huruf d "melakukan tindakan - tindakan pencegahan tindak pidana korupsi" ini menjadi pijakan kewenangan yang kemudian dipertegas pada pasal 13 huruf a "melakukan pendaftaran dan pemeriksaan terhadap laporan harta kekayaan penyelenggara negara". Negara mempunyai komitmen untuk memberantas korupsi terutama dengan melakukan tindakan pencegahan. Penyelenggara teknis, KPU, menegaskan melalui PKPU 13 tahun 2020 pasal 4 ayat 1 (k) dalam syarat pencalonan menyerahkan harta kekayaan pribadi" kemudian pada pasal 42 ayat 1 (i) "surat tanda terima penyerahan laporan harta kekayaan penyelenggara negara dari instansi yang berwenang memeriksa laporan harta kekayaan penyelenggara negara sebagai bukti pemenuhan persyaratan calon..." Hal ini sebagai dokumen administratif untuk melengkapi syarat bakal calon kepala dan wakil kepala daerah. Dalam proses ini dilakukan sebagai komitmen transparansi atas harta kekayaan pribadi individu. KPU hendaknya menerima salinan form LHKPN tidak hanya tanda terima pelaporan. Bawaslu sebagai pengawas pemilu juga diberikan hal yang sama. Untuk selanjutnya salinan form LHKPN digunakan oleh KPU sebagai bagian pendukung laporan dalam LPPDK melalui LADK sebagai termin awal pelaporan yang mencerminkan pendapatan / harta kekayaan pasangan calon. Dengan demikian LHKPN mampu menjadi bagian laporan yang mengidentifikasi apakah pasangan calon melaporkan harta kekayaan sesuai dengan pendapatannya atau tidak. Penting untuk memberikan keluasan kewenangan kepada KPK sebagai majelis pemeriksa sejak 
penyelidikan - penyidikan - hingga penuntutan dalam melakukan penindakan hukum terhadap hasil verifikasi LHKPN. Sementara Bawaslu - PPATK - KPK hendaknya mempunyai jalur khusus pelaporan yang mampu diawasi oleh masyarakat sipil sehingga ada transparansi model pelaporan yang mampu mengkonfirmasi data kebenaran lapangan terhadap data teknis yang dijabarkan oleh KPU. Namun pada klausul Undang-Undang yang menjadi leading sector adalah KPK. Sehingga penyerahan bukti form LHKPN hanya berfungsi sebagai identifikasi ketertiban dalam penyerahan berkas pencalonan. Perbawaslu Nomor 10 tahun 2017 pasal ayat 2 (4) "Pemeriksaan dan penilaian sebagaimana dimaksud pada ayat (2) dilakukan dengan memperhatikan kelengkapan, keabsahan, dan kebenaran dokumen pendaftaran pencalonan. "Menegaskan bahwa fungsi pengawasan Bawaslu pada ranah administratif yakni dokumen tersebut diserahkan secara lengkap dan berkategori benar. Dilansir dari laman Tirto. id Afifudin menegaskan "LHKPN penting untuk menjadi indikator kepatutan dan kelayakan jumlah sumbangan pribadi calon. Pada penyerahan LHKPN, Bawaslu hanya memastikan pasangan calon memastikan lajur form sudah diisi sesuai dengan kaidah penulisan". Maka kewenangan untuk menjadikan bagian pendukung laporan dalam LPPDK melalui LADK tidak dapat dilakukan. Pada studi ini, sumber LHKPN pasangan calon Pilgub Jabar diperoleh dari laman informasi Tirto.id yang sumber datanya mengacu kepada acch. kpk.go.id.-Tabel yang tersaji dibawah ini:

\begin{tabular}{|l|l|l|}
\hline No & $\begin{array}{l}\text { Nama } \\
\text { Kandidat } \\
\text { Pasangan } \\
\text { Calon }\end{array}$ & Nominal Jumlah \\
\hline 1. & $\begin{array}{l}\text { Deddy } \\
\text { Mizwar }\end{array}$ & $\begin{array}{l}\text { RP. 23.772.024.525 } \\
\text { dan USD 35.385 }\end{array}$ \\
\hline 2. & Dedi Mulyadi & RP.3.164.425.514 \\
\hline 3. & $\begin{array}{l}\text { Ridwan } \\
\text { Kamil }\end{array}$ & RP.8.282.049.675 \\
\hline 4. & $\begin{array}{l}\text { UU Ruzhanul } \\
\text { Ulum }\end{array}$ & RP.3.116.778.194 \\
\hline 5. & Sudrajat & $\begin{array}{l}\text { RP.3.440.294.898 } \\
\text { dan USD 295.000 }\end{array}$ \\
\hline 6. & Syaikhu & RP.945.180.581 \\
\hline 7. & $\begin{array}{l}\text { Tb } \\
\text { Hassanudin }\end{array}$ & RP.9.259.651.793 \\
\hline 8. & $\begin{array}{l}\text { Anton } \\
\text { Charlian }\end{array}$ & Tidak ditemukan \\
\hline
\end{tabular}

Sumber: Laporan LHKPN paslon pilgub 2018 (https://tirto.id/cCZp \& https://tirto.id/cC5F http:// www.cnnindonesia.com/)

Sementara pada laporan Pilgub Jatim diperoleh informasi yang berasal dari laman kpujatim.go.id dengan menu akses info pilkada, hanya didapatkan data dengan model tanda terima LHKPN yang berasal dari KPK. 


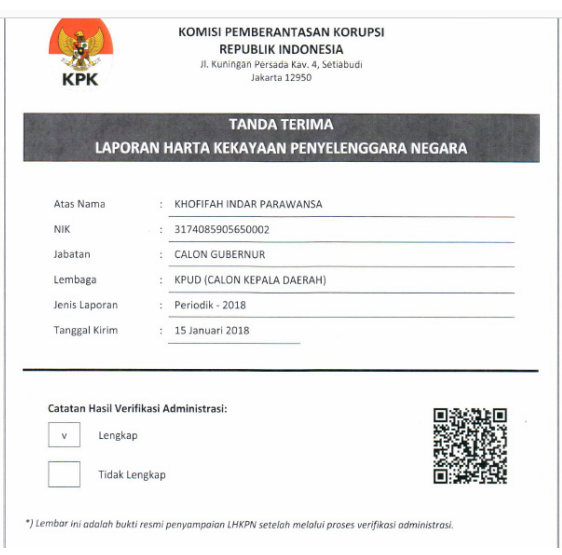

Sumber: Laporan LHKPN paslon pilgub 2018 (www.kpujatim.go.id)

Berdasarkan rilis tersebut didapatkan bukti 3 calon kandidat yakni Khofifah Indar Parawansa, Emil Lestiarto Dardak dan Syaifullah Yusuf. Untuk kontestan a/n Puti Guntur Soekarno tidak ditemukan tanda terima bukti tersebut. Sehingga untuk memperoleh angka jumlah nominal laporan, diperoleh dari laman informasi cnn.indonesia. com. Sumber datanya berasal dari pengumuman rilis media KPU Jatim. Dalam informasi laman tersebut juga menjabarkan bahwa laporan harta kekayaan tersebut telah melalui proses pemeriksaan di Komisi Pemberantasan Korupsi (KPK).

\begin{tabular}{|l|l|l|}
\hline No & $\begin{array}{l}\text { Nama } \\
\text { Kandidat }\end{array}$ & Nominal \\
\hline 1. & $\begin{array}{l}\text { Khofifah } \\
\text { Indar } \\
\text { Parawansa }\end{array}$ & $\begin{array}{l}\text { RP. } \\
23.552 .699 .762\end{array}$ \\
\hline 2. & $\begin{array}{l}\text { Emil Lestiarto } \\
\text { Dardak }\end{array}$ & RP. 8.254.061.762 \\
\hline 3. & $\begin{array}{l}\text { Syaifullah } \\
\text { Yusuf }\end{array}$ & $\begin{array}{l}\text { RP. } \\
17.598 .885 .769\end{array}$ \\
\hline 4. & $\begin{array}{l}\text { Puti Guntur } \\
\text { Soekarno }\end{array}$ & RP. 1.865.423.077 \\
\hline
\end{tabular}

Sumber: Laporan LHKPN paslon pilgub 2018 (www.cnnindonesia. com)

Penyelenggaraan penyampaian laporan LHKPN Dalam jabaran pemilu berintegritas sebagaimana konsepsi Norris (2012) Dari dua pelaporan diatas dapat dianalisis bahwa proses berawal dari sumber data akses untuk mendapatkan kerincian data dalam jenis-jenis harta kekayaan. Pada informasi LHKPN paslon Jabar diperoleh dari laman website konvensional dengan jumlah nominal masingmasing calon. Sementara informasi LHKPN Paslon Jatim mendapatkan form paslon Jatim dari laman KPU provinsi hanya 3 calon, sementara untuk calon a/n Puti Guntur Soekarno tidak diperoleh form pelaporan. Untuk nominal jumlah kekayaan diperoleh dari laman website konvensional. Melalui data ini sulit untuk mengukur jumlah harta dan dampak terhadap pendapatan yang nantinya bisa digunakan sebagai pijakan awal untuk 
melihat instrumen awal pelaporan yakni pada aspek LADK, sumber pendanaan awal dana kampanye. Sementara tampak bahwa penyajian data pada pelaporan LHKPN hanya menginformasikan jumlah harta kekayaan namun tidak ada penilaian akuntabilitas yang dilakukan oleh KPK. Terlebih KPU sebagai penyelenggara teknis pemilihan umum. Sehingga berkas LHKPN bagi penyelenggara pemilu hanya sebatas penerimaan surat tanda lapor dari KPK. Sementara menurut kajian yang disampaikan oleh Suryono (2015) mengungkapkan bahwa LHKPN bagi penyelenggara tidak dapat memberikan efek jera karena sifatnya hanya "benda mati" yakni tidak memberikan pengaruh apapun selain sanksi administratif. Elih Dalilah, dkk (2018) memberikan argumen kuat bahwa dari data tabulasi silang antara data survey (dana pribadi yang dikeluarkan) dan data LHKPN (total harta kas dan total harta kekayaan) studi pada calon pilkada 2015, 2017 dan 2018 terdapat calon kepala/wakil kepala daerah yang melebihi harta kas dan total harta kekayaan. Melalui beberapa kajian diatas data pelaporan LHKPN adalah pendukung keabsahan berkas pencalonan yang dilegitimasi melalui peraturan baik UU 30/2012 mengenai KPK dan UU 6/2020 mengenai pelaksanaan pilkada. Pada proses dan hasil yang diterima dalam penyelenggaraan pilkada, berkas LHKPN hanya mengandalkan kejujuran dari pasangan calon tanpa seorangpun yang dapat membuktikan apakah data tersebut benar secara realitas dan menunjukkan loyalitas pasangan calon dalam mendukung pelaksanaan pilkada yang berintegritas. Dengan dua perbandingan data diatas baik Prov Jabar dan Prov Jatim, tergambar bahwa muncul ketidakfektifan pelaporan karena data tersebut tidak menunjukkan akuntabilitas kekayaan. Jabaran tersebut hanya sebatas tampilan laporan saja. Di sisi lain penyajian data yang disampaikan oleh kanal KPK acch. kpk.go.id juga tidak mudah untuk diakses, sehingga harus bersurat khusus untuk mendapatkan data yang dibutuhkan. 4 pasangan calon di Jabar dan 2 pasangan calon di Jatim, terdapat 1 kandidat Jabar, Anton Charlian yang tidak menyerahkan LHKPN dan 1 kandidat Jatim, Puti Guntur Soekarno tidak didapatkan berapa informasi kekayaan yang dimiliki. Sebagaimana kajian Dalilah (2018) dan Suryono (2015) disampaikan pada paragraf sebelumnya, ditemukan data bahwa tidak ada sanksi administratif kepada 2 kandidat tersebut terkait pelaporan LHKPN. KPU provinsi tidak melakukan proses check and balances karena hal ini hanya menjadi syarat formil pencalonan pilkada baik yang diusulkan parpol/perseorangan tanpa unsur pidana. 


\subsection{Potret}

\section{Pelaporan LPPDK}

Upaya untuk mewujudkan pemilu berintegritas salah satunya diwujudkan dari pelaksanaan proses pendanaan laporan transaksi keuangan yang menjunjung asas transparansi dan akuntabilitas. Landasan hukum terhadap pelaksanaan LPPDK terdapat dalam UU 6/2020 pasal 187 ayat 5, 6, 7 dan 8 yang masing-masing mengatur pembatasan nominal dana kampanye, larangan untuk menerima dan memberi dana kampanye melebih batas yang ditentukan, larangan memberikan keterangan yang tidak benar dan setiap calon yang menerima dana kampanye melebihi batas yang ditentukan diminta untuk menyetorkan kelebihan dana tersebut ke kas negara. Kemudian diperkuat dengan PKPU 13/2020 pasal 1 poin 37 menyebutkan bahwa LPPDK adalah pembukuan yang memuat seluruh penerimaan dan pengeluaran dana kampanye. Dalam hal ini adalah LADK dan LPSDK yang kemudian dikalkulasi akhir menjadi LPPDK. Konsep ini menjunjung tinggi prinsip pilkada yang berintegritas sebagaimana dijelaskan dalam sub bahasan teori yang sudah diulas pada paragraph sebelumnya bahwa dalam kesepakatan Global Commission on Election seperti dikutip Pasaribu \& Suradinata (2018) dijelaskan bahwa Integritas pemilu terlihat jika pemilu dapat terlaksana berdasarkan atas prinsip pemilu yang demokratis sehingga menghasilkan badan anti korupsi yang tegas, free and fair election dan adanya lembaga HAM yang mampu melindungi warganya juga mendukung adanya aspek integritas dalam sebuah proses pemilihan. Dapat dikatakan bahwa diksi "badan anti korupsi" yang ada dalam teori tersebut mensyaratkan sebuah tata kelola penyelenggaraan yang merujuk kepada sikap anti korupsi.

Penyerahan berkas
administratif LADK berupa penyampaian perolehan dana awal kampanye disertai informasi buku rekening tim kampanye pasangan calon. Aturan dalam LADK tidak mengatur batas minimal dana yang berada dalam laporan tersebut. Kepatuhan yang dinilai adalah supporting dokumen dan surat pernyataan penyumbang. LADK yang berisikan laporan awal dapat menjadi muara penyelidikan. Kemudian LPSDK sebagai tahapan kedua yakni pembukuan yang memuat seluruh penerimaan yang diterima oleh pasangan calon jumlah laporan sumbangan yang diperoleh pasangan calon. Kemudian Laporan Penerimaan dan Pengeluaran Dana Kampanye (LPPDK) adalah pembukuan yang memuat seluruh penerimaan dan pengeluaran dana kampanye. Studi penelitian ini mendasarkan LPPDK sebagai sumber pertanggungjawaban aktifitas kampanye pasangan calon yang berujud barang, uang dan jasa. Hal ini 
dikarenakan terdapat pidana yang menyertai sebagaimana UU 6 tahun 2020 pasal 187 ayat 5 "Setiap orang yang memberi atau menerima dana Kampanye melebihi batas yang ditentukan sebagaimana dimaksud dalam Pasal 74 ayat (5), dipidana dengan pidana penjara...." Dan ayat 6 "Setiap orang yang dengan sengaja menerima atau memberi dana Kampanye dari atau kepada pihak yang dilarang sebagaimana dimaksud dalam Pasal 76 ayat (1) dan/ atau tidak memenuhi kewajiban sebagaimana dimaksud dalam Pasal 71, dipidana dengan pidana penjara..." Ayat 7 "Setiap orang yang dengan sengaja memberikan keterangan yang tidak benar dalam laporan dana Kampanye sebagaimana diwajibkan oleh Undang-Undang ini, dipidana dengan pidana penjara..." dan Ayat 8 "Calon yang menerima sumbangan dana Kampanye dan tidak melaporkan kepada KPU Provinsi dan KPU Kabupaten/ Kota dan/atau tidak menyetorkan ke kas negara, dipidana dengan pidana penjara..." selain itu juga terdapat aturan di PKPU 13/2020 pasal 54 "Pasangan Calon yang terlambat menyampaikan LPPDK kepada KPU Provinsi/KIP Aceh atau KPU/KIP Kabupaten/ Kota sampai batas waktu yang ditentukan sebagaimana dimaksud dalam Pasal 34 ayat (1) dan ayat (2), dikenai sanksi berupa pembatalan sebagai Pasangan Calon". Kelima klausul peraturan diatas menjelaskan secara implisit bahwa bahwa LPPDK menjadi muara terakhir punishment pasangan calon yang melakukan pelanggaran dalam pendanaan kampanye. Analis ICW, Donal Fariz dalam Afiffudin (2019) menyebutkan bahwa potensi manipulasi dana kampanye terjadi dalam 3 tahap yakni pemasukan income, pengeluaran spending dan pelaporan reporting. Pihak KPU telah membuka pelayanan help desk untuk membantu tim kampanye paslon dalam menyusun pelaporan dana kampanye. Hal ini dalam rangka mewujudkan pelaporan yang legal, akuntabel dan transparan. Bawaslu sebagai pengawas pemilu meneruskan hasil pengawasan kepada PPATK guna melakukan penelusuran dan memantau aktivitas keuangan rekening pasangan calon. Melalui hal ini Bawaslu juga dapat mendata aktivitas kampanye yang sudah terdaftar melalui Surat Tanda Terima Pemberitahuan (STTP) untuk kemudian diukur berapa prakiraan jumlah cost dan buying yang terjadi.Sehingga akan muncul mekanisme kontrol terhadap pembiayaan yang dimulai dari LADK, LPSDK hingga LPPDK. Namun seperti yang diungkap dalam tesis Nusantara (2019) pengumuman terkait hasil audit yang dilakukan di akhir periode atau setelah pemilu berakhir, membuat informasi terkait daftar penyumbang dan aktivitas penggunaan dana kampanye tidak memberikan nilai informasi yang berharga bagi pemilih karena 
baru disampaikan pada bagian akhir jelang seluruh tahapan usai. Selain itu pendeknya waktu pelaporan LPPDK dengan tahapan masa tenang menyebabkan akses pemeriksaan terhadap laporan menjadi sangat terbatas. Hasil audit yang diberikan oleh KAP yang dilakukan selama 15 hari hanya berupa asersi atau tingkat kepatuhan. Bukan audit kebenaran. Belum ada instrument / alat ukur yang disiapkan penyelenggara. Meskipun secara aturan pidana sudah disiapkan secara komprehensif.

Hasil temuan laporan LPPDK pada studi ini dengan menggunakan konsepsi Norris (2012) dimulai dari Hasil laporan tersebut tertuang dalam pengumuman KPU Jabar Nomor 611/ PL.03.5-PU/ 32/ Prov/ VII/ 32/ 2018 tentang hasil audit laporan dana kampanye peserta pemilihan gubernur dan wakil gubernur jawa barat tahun 2018.

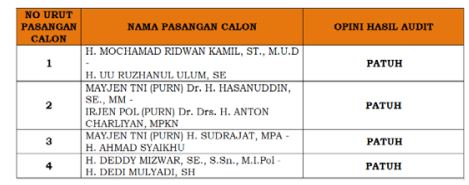

Sumber : keputusan KPU provinsi Jawa Barat tahun 2018

Sementara data yang tersaji dalam LPPDK Pilgub Jatim, KPU provinsi mengumumkan hasil audit yang menyatakan kedua pasangan calon mempunyai opini patuh. Mereka tidak melanggar jumlah maksimal dana kampanye yang ditetapkan oleh KPU Jatim yaitu sebesar RP 494 Miliar. Hasil laporan tersebut diterbitkan dalam surat pengumuman KPU Nomor 105/ PL.03.5-Pu / 35/ PROV/ VII/ 2018 tentang hasil audit laporan dana kampanye peserta pemilihan gubernur dan wakil gubernur jawa timur tahun 2018.

\begin{tabular}{|c|c|c|}
$\begin{array}{c}\text { NO URUT } \\
\text { PASANGAN } \\
\text { CALON }\end{array}$ & \multicolumn{1}{|c|}{ NAMA PASANGAN CALON } & $\begin{array}{c}\text { OPINI DALAM } \\
\text { LAPORAN HASI } \\
\text { AUDIT }\end{array}$ \\
\hline 1 & $\begin{array}{l}\text { Dra. KHOFIFAH INDAR PARAWANSA \& } \\
\text { DR. EMIL ELESTIANTO DARDAK, M.Sc. }\end{array}$ & PATUH \\
\hline 2 & $\begin{array}{l}\text { H. SAIFULLAH YUSUF \& } \\
\text { HJ. PUTI GUNTUR SOEKARNO }\end{array}$ & PATUH \\
\hline
\end{tabular}

Sumber : keputusan KPU provinsi Jawa Timur tahun 2018

Tesis yang didapat dari dua laporan, ditemukan bahwa penyelenggara teknis pemilihan, baik KPU Prov Jatim dan KPU Prov Jabar tidak memberikan informasi terbuka kepada publik terkait hasil LPPDK. Sehingga hasil LPPDK hanya diketahui oleh pihak penyelenggara dan auditor. Namun mereka melakukan keterbukaan informasi terhadap hasil audit KPU, yakni memenuhi standar pelaporan dengan narasi Patuh. Hal ini tidak menunjukkan hal yang substansif, cukup pada proses kepatuhan dalam menjalankan proses atau regulasi yang tercantum. Pada kerangka hukum pemidanaan atas hasil LPPDK dua paslon di Jatim dan empat paslon di Jabar tidak menemukan hasil yang signifikan. Dalam studi ini penulis mendapatkan akses laporan tersebut melalui data yang dilansir oleh media, bukan dari kanal data kpu "info pilkada" dikarenakan data tersebut tidak ada di lajur yang sudah disediakan. Padahal jika menilik kesiapan aplikasi 
SIDAKAM, yang kemudian dapat meminta asistensi tim helpdesk kpu yang berada di setiap daerah, seharusnya informasi ini masih bisa diakses dalam beberapa waktu mendatang sebagai dokumen terpadu. Data yang disajikan dalam LPPDK ini melalui pemberitaan pada Pilgub Jabar 2018. Dana kampanye pilkada yang terkumpul keseluruhan pasangan calon adalah Rp. 19,7M. Dalam pengawasanyang dilakukan oleh Bawaslu Jabar (2018) juga dikatakan bahwa ditemukan adanya penerimaan sumbangan dana kampanye yang tidak jelas dari perorangan maupun perusahaan. Sebagaimana UU 6 tahun 2020 Pasal 187 ayat $7 \& 8$ Hal ini seharusnya dapat menjadi pijakan untuk menindak pasangan calon yang tidak memenuhi ketentuan tersebut, namun aspek penegakan hukum masih sebatas temuan yang sulit untuk dilakukan pembuktian. Tidak ditemukan apakah LPPDK 6 pasangan calon sudah sesuai dengan form pelaporan yang diberikan oleh KPU sebagaimana format Formulir Model LPPDK2-PARPOL dalam PKPU 13 tahun 2020. KPU provinsi Jawa Barat dan Jawa Timur tidak memberikan informasi terkait form LPPDK yang dilaporkan. Sementara hasil informasi dari auditor yang ditunjuk oleh KPU hanya berwujud informasi patuh dan tidak patuh. Ohman (2013) dalam reporting requirements hasil studi IDEA mengungkapkan bahwa sesungguhnya model pelaporan transparansi keuangan itu sederhana, yakni partai politik dan kandidat pasangan calon mengirimkan laporan berkala ke otoritas publik, laporan tersebut menginformasikan kepada semua pemilih tentang pendanaan kompetisi politik. Dalam prakteknya di negaranegara anglophone misalnya tidak semuanya menerapkan aturan ideal tersebut, Di Australia tidak ada format pengaturan yang spesifik, sementara di Amerika Serikat laporan keuangan bulanan diperlukan. Tata pengelolaan keuangan di Indonesia juga sesungguhnya mengadopsi aturan tersebut dengan memberikan klasifikasi pelaporan dalam sepanjang masa kontestasi mulai dari Saldo Rekening Khusus Dana Kampanye (RKDK), Laporan Awal Dana Kampanye (LADK), Laporan Penerimaan Sumbangan Dana Kampanye (LPSDK). Dengan klasifikasi tersebut diharapkan mampu menemukan kejanggalan ataupun private donations (pendanaan pribadi) dan public fundings (pendanaan dari kelompok/ umum) yang melebihi batas yang ditentukan. Bawaslu dalam hasil pengawasan pilkada 2018 seperti diungkap oleh Putra (2018) menemukan sekitar total Rp. 14 Milyar dana kampanye yang di gunakan oleh Paslon di luar rekening khusus yang telah di laporkan ke KPU, dengan rincian Rp10.805.174.636 di gunakan pada tingkat kabupaten/kota dan Rp3.984.157.334 di gunakan pada tingkat provinsi. Hasil pengawasan laporan dana kampanye dari 
organisasi masyarakat sipil, Jaringan Pendidikan Pemilih untuk Rakyat (JPPR), Transparency International Indonesia (TII), Perkumpulan untuk Pemilu dan Demokrasi (Perludem) dan Indonesian Corruption Watch (ICW) sejauh ini hanya dapat dikategorikan menjadi masukan kepada KAP tanpa bisa menjadi prasyarat atas proses audit yang sedang berlangsung. Proses yang dilakukan adalah audit kepatuhan bukan audit kebenaran kampanye. Dalam kajian yang dilakukan Sukmajati \& Disyacitta (2019) mengemukakan bahwa laporan tidak mencerminkan realitas yang sebenarnya di lapangan. Hal ini karena sisi kemauan politik (political will) yang relatif rendah dan sistem serta mekanisme audit dana kampanye yang diatur tidak memunculkan prinsip transparansi dan akuntabilitas. Dalam temuan IDEA yang dikaji Ohman (2013) dikatakan bahwa penataan keuangan pendanaan kampanye sangat dipengaruhi oleh sistem politik secara keseluruhan termasuk faktor struktural kelembagaan dan efektifitas peraturan keuangan politik. Termasuk dari wealthy interests (orang kaya berpengaruh) dan kurangnya kemauan untuk mengungkap pihak yang terlibat bahkan keengganan mereformasi peraturan. Kajian tersebut menguatkan realitas bahwa meskipun pasal yang berupaya menegakkan aspek pidana pendanaan kampanye seperti dalam UU 6/2020 Pasal 187 ayat
5, 6, 7 dan ayat 8 telah diatur sedemikian rupa namun sampai hari ini belum mampu menjadi alat penyelesaian pertanggung jawaban terkait integritas laporan. Dikarenakan ada regulasi yang tidak sejalan dalam implementasi UU dan jabaran pada peraturan teknis yakni, PKPU Dana kampanye. Rilis data ICW 2018 sudah mencatat potensi korupsi di Pilkada serentak 2018 yakni salah satunya adalah manipulasi laporan dana kampanye. Hal ini membenarkan kondisi obyetif yang terjadi. Faktanya hingga pilkada serentak gelombang ketiga, belum ada kontestan yang mendekam di sel penjara akibat ketidakbenaran laporan dana kampanye. Pendiskualifikasian pencalonan yang dilakukan KPU kabupaten Sinjai, Sulawesi Selatan kepada pasangan pilbub 2018 yakni Sabirin Yahya-Mahyanto, hanya di akibatkan pasangan tersebut tidak menyerahkan laporan akhir penerimaan dan pengeluaran dana kampanye (LPPDK).

Mengacu pada dua tesis terkait hasil temuan model pelaporan LHKPN dan model pelaporan LPPDK pada 6 pasangan calon di kedua provinsi. Regulasi LHKPN masih mengalami kelemahan dari sisi siapa yang berkuasa melakukan penyidikan dan penangkapan. Regulasi LPPDK sudah mempunyai implikasi baik namun implementasi yang diturunkan melalui PKPU masih lemah secara aspek transparansi. Hal ini dikarenakan laporan hanya 
bisa diakses oleh pihak KPU dan auditor yang ditunjuk. Dalam menerima salinan pelaporan sebagai KPU beserta jajarannya hanya berkewenangan memeriksa secara form kelengkapan. Fungsi auditor hanya menerjemahkan terhadap laporan yang ada. Form pelaporan LHKPN yang diserahkan kepada KPU tidak memuat jenis harta kekayaan hanya selembar tanda laporan. KPK tidak diberi kewenangan menganalisis terkait hasil kekayaan pasangan calon yang diteruskan kepada pihak KPU selaku pengelola teknis pemilihan.

\section{Simpulan}

Berdasarkan hasil analisa permasalahan pada bab sebelumnya, LHKPN dan LPPDK sebagai sebuah upaya untuk mewujudkan pemilu berintegritas masih menemukan kendala secara implementasi, khususnya dalam aspek akuntabilitas dan transparansi. Sehingga untuk mewujudkan integritas dalam sistem kontestasi kepemimpinan daerah tidak bisa dijadikan sebagai tolak ukur/ landasan proses. Perlu upaya perlu terobosan untuk menguatkan regulasi dan peran masyarakat sipil untuk memberikan masukan terhadap proses tahapan pelaporan LHKPN dan LPPDK. Secara umum kasus Jatim dan Jabar menunjukkan situasi umum pengelolaan dana kampanye di Indonesia. Terdapat beberapa hal yang perlu diperhatikan, pertama LHKPN dilaporkan dua kali sepanjang masa tahapan pilkada, yakni pada saat pendaftaran pasangan calon dan setelah tahapan dana kampanye selesai di audit oleh KAP yang ditunjuk KPU. Dengan demikian akan tergambar berapa harta kekayaan yang dimiliki oleh para calon kepala daerah. kedua, Memperbaiki pola Sistem Informasi Dana Kampanye (SIDAKAM) yang sudah disiapkan oleh KPU. Sistem ini harus di desain online. Sehingga laporan calon kepala daerah, dapat diakses baik oleh penyelenggara, peserta ataupun pemilih selama masa tahapan pilkada berlangsung. Ketiga, Pada LPPDK, diperlukan pelaporan awal dana kampanye dengan jurnal buku transaksi harian. Sehingga calon mampu memantau secara lebih rigid. Transaksi yang dilakukan hanya dalam satu akun, yakni $a / n$ calon kontestan atau yang ditunjuk melalui surat kuasa. Sehingga partai politik juga mampu memberikan legitimasi kepada salah satu pihak yang melakukan bentuk pertanggungjawaban dalam laporan tersebut. Keempat, Dalam itikad ini perlu untuk melakukan pembenahan kerangka hukum dalam UU Pemilu yang disertai dengan UU Partai Politik, termasuk mengfungsikan unsur yudikatif yang mampu memberikan efek jera kepada partai politik sebagai kontestan pemilu. Dengan ini diharapkan terdapat perubahan dalam bentuk kontrak politik karena tekanan pressure masyarakat pemilih yang kritis dan cerdas. Guna menghadirkan sebuah iklim demokratis yang terhindar dari electoral autocracies dan kepemimpinan bermental 'pelayan' bagi masyarakat sehingga tujuan pembangunan kesejahteraan daerah tercapai. 


\section{DAFTAR PUSTAKA}

\section{Buku, Artikel, dan Jurnal}

Adams, J. (2001). Risk. London: Routledge.

Afifuddin, M. (2020). Membumikan Pengawasan Pemilu Mozaik Pandangan dan Catatan Kritis dari Dalam. Jakarta: Elex Media Komputindo.

Budiharjo, M. (2013). Dasar-Dasar Ilmu Politik. Edisi Revisi, Jakarta: PT Gramedia.

Dalilah E, Selawati B, dkk. (2019). Benturan Kepentingan Pada Pendanaan Pilkada. Jurnal Antikorupsi INTEGRITAS, 5 (1), Jakarta, hlm 181-188. https :// doi. org/ 10. 32697 / integritas. v5i1. 391

Fernandez, A. (2019, September 16). Problem Akut Partai Politik. Kompas. hlm 6 Fariz, D, Ilyas, F. (2019) Manipulasi Dana Kampanye Pemilihan Presiden dan Wakil Presiden. Buku Pembiayaan Pemilu di Indonesia, Jakarta: Bawaslu RI. Hal 25-45.

Gaffar, M Janedri. (2013). Demokrasi Dan Pemilu di Indonesia, Jakarta: KONstitusi press

Grynasviki Jeffrey D. (2010). Partisan Bonds: Political Reputations and Legislative Accountability. UK: Cambridge University Press

Herbowo, N, Purnamasari, D. Sinyal Bahaya Politik Uang. (2020, Juni 16). Kompas. Hal 4

Larasati D, Latifah. (2018). Demokrasi dan Organisasi Masyarakat Sipil: Malang Corruption Watch. Jurnal Sospol, Vol 4 No. 1, hal 168-184.

Nusantara, C, Galuh. (2019). Sistem Pelaporan Dana Kampanye Berbasis Prinsip Transparansi dan Akuntabilitas (Studi Kasus Laporan Dana Kampanye Pasangan Calon Pada Pemilihan Bupati dan Wakil Bupati Blora tahun 2015). Kompilasi Ringkasan Tesis Tata Kelola Pemilu Edisi I Tahun 2019 www.journal.kpu.go.id, hal 115-132.

Norris, P. (2012). Making Democratic Governance Work How Regimes Shape Prosperity, Welfare, and Peace. New York: Cambridge University Press

Ohman, M. (2014). Getting the Political Finance System Right. Falguera. E \& Jones.S (Eds), Funding of Political Parties and Election Campaigns A Handbook on Political Finance (hlm 12-33). Sweden, Stockholm: International IDEA.

Pasaribu, Tota, Sumadinata, Setiabudi, dkk. (2018). Pemilu Berintegritas (Studi Pada Pendaftaran Pemilih Terhadap Pengguna Surat Keterangan Domisili Dalam Pilkada Samosir tahun 2015). Journal of Governance Untirta Banten Volume 3, Issue 2, December 2018, hlm 168-183. http://dx.doi. 
Plutzer, E. (2018). Demographics and the Social Bases of Voter Turnout. Fisher, J \& Fieldhouse, E, dkk (Eds), The Routledge Handbook of Elections, Voting Behavior and Public Opinion (hlm 69-82). New York: Routledge

Putra, H. (2018). Mendorong Transparansi dan Akuntabilitas Dana Kampanye pada Penyelenggaraan Pilkada Serentak Tahun 2018. JPPUMA: Jurnal Ilmu Pemerintahan dan Sosial Politik UMA (Journal of Governance and Political Social UMA) 6 (2). hlm 112-121. DOI: 10.31289/jppuma.v6i2.1622

Reynolds, A, Reilly, B. dkk (2016). Desain Sistem Pemilu: Buku Panduan Baru Internasional IDEA. Jakarta: Perludem.

Supriyanto, D \& Wulandari, L. (2013). Basa Basi Dana Kampanye Pengabaian Prinsip Transparansi dan Akuntabilitas Peserta Pemilu. Jakarta: Perludem.

Sukmajati, Mada, Disyacitta, Fikri. (2019). Pendanaan Kampanye Pemilu Serentak 2019 di Indonesia: Penguatan Demokrasi Patronase?. Jurnal Antikorupsi INTEGRITAS, 5 (1), Jakarta. hlm 75-95. https://doi.org/10.32697/ integritas.v5i1.398

Tornquist, O.(2005). The Political Deficit of Substantial Democratisation. Harris, $S$ \& Stokke, K (Eds), Politicising Democracy The New Local Politics of Democratisation (hlm 201-222). New York: Palgrave Macmillan

Suryono, Ahmad. (2018). Laporan Harta dan Kekayaan Penyelenggara Negara (LHKPN) Progresif Sebagai Tindakan Pencegahan Korupsi. Kumpulan Tulisan Peran Perguruan Tinggi dalam Upaya Penanggulangan Korupsi, hlm 297-308

Hafidz, Buku Laporan Pengawasan Dana Kampanye JPPR Tahun 2015. Jakarta: JPPR

Buku Panduan Sistem Integritas Partai Politik (SIPP). Jakarta: LIPI-KPK

\section{Website}

Muhammad (2019, Juli 10). Prof Muhammad paparkan lima syarat pemilu berintegritas di acara BICOIPG 2019. Diakses dari https://dkpp.go.id/ prof-muhammad-paparkan-lima-syarat-pemilu-berintegritas-di-acarabicoipg-2019/ diunduh pada 22 Juli 2020 pukul 20.32 WIB

Wardani, E, Budi Sri (2016, Agustus 25). 8 Kunci Pemilu Berintegritas Hasil AESF Bali. Diakses dari https://www.kpu-lampungutara.go.id/2016/08/25/8-kuncipemilu-berintegritas-hasil-aesf-bali/ diunduh pada 21 Juli 2020 pukul 15.30

Ade (2018, January 29). LHKPN, Kebijakan Tanpa Taji. Diakses dari https:// antikorupsi.org/id/article/lhkpn-kebijakan-tanpa-taji diunduh pada 4 juli 
Sasmito, E (2018, April 12) KPU Umumkan harta Calon di Pilgub Jatim, Khofifah Paling Kaya. Diakses dari https://www.cnnindonesia.com/ pilkadaserentak/ nasional/ 20180412145052-32 290344/ kpu-umumkanharta-calon-di-pilgub-jatim-khofifah-paling-kaya diunduh pada 24 juli 2020 pukul 11.30 WIB

Hafidz, M (2015, Desember 8) Laporan Dana Kampanye Pilkada Dinilai Tak Transparan. Diakses dari https://www.cnnindonesia.com/ nasional/20151208184145-32-96876/laporan-dana-kampanye-pilkadadinilai-tak-transparan diunduh pada 23 Juli 2020 pukul 12.30

Bayu, J (2018, Januari 11) ICW Catat 10 Potensi Korupsi di Pilkada Serentak 2018. Diakses dari https://katadata.co.id/yuliawati/berita/5e9a560b77d67/ icw-catat-sepuluh-potensi-korupsi-di-pilkada-serentak-2018 diunduh pada 27 juli 2020 pukul 10.58

Damaledo, D (2018, Januari 9) Kandidat Pilgub Jawa Barat 2018 Terkaya Versi LHKPN. Diakses dari https://tirto.id/kandidat-pilgub-jawa-barat-2018terkaya-versi-Ihkpn-cCZp diunduh pada 24 juli 2020 pukul 11.40 WIB

Sakti, C (2018, Juli 12) KPU Jatim Terima Audit Laporan Dana Kampanye Pilgub Jatim, Dua Paslon Punya 'Opini Patuh'. Diakses dari https://jatim. tribunnews.com/2018/07/12/kpu-jatim-terima-audit-laporan-danakampanye-pilgub-jatim-dua-paslon-punya-opini-patuh. Diunduh pada 27 juli 2020 pukul 13.10 WIB

Taher, P (2018, Januari 10) "Paslon Tak Bisa Ikut Pilkada 2018 Tanpa Lapor Harta Kekayaan", diakses dari https://tirto.id/cC1V diunduh pada 5 oktober 2020 pukul 06.39 WIB

\section{Peraturan}

UUD 1945

UU 6 Tahun 2020 Tentang Pilkada

UU 30 Tahun 2012 Tentang KPK

PKPU 13 Tahun 2020 Tentang Pelaksanaan Pilkada dalam kondisi bencana non alam Covid-19

PKPU 5 Tahun 2017 tentang Dana Kampanye Pilkada

SK KPU Jatim Nomor 105/ PL.03.5-Pu / 35/ PROV/ VII/ 2018 tentang hasil audit 
laporan dana kampanye peserta pemilihan gubernur dan wakil gubernur Jawa Timur tahun 2018

SK KPU Jabar No 611/ PL.03.5-PU/ 32/ Prov/ VII/ 32/ 2018 tentang hasil audit laporan dana kampanye peserta pemilihan gubernur dan wakil gubernur Jawa Barat tahun 2018. 